\title{
Insulin-Like Growth Factor Binding Proteins-3 and -5: Central Mediators of Fibrosis and Promising New Therapeutic Targets
}

\author{
Kristen L. Veraldi and Carol A. Feghali-Bostwick*
}

\author{
The Division of Pulmonary, Allergy, and Critical Care Medicine, and Pittsburgh Scleroderma Center, Department of \\ Medicine, University of Pittsburgh School of Medicine, Pittsburgh, Pennsylvania, USA
}

\begin{abstract}
Fibrosis involves an orchestrated cascade of events including activation of fibroblasts, increased production and deposition of extracellular matrix components, and differentiation of fibroblasts into myofibroblasts. Epithelialmesenchymal cross-talk plays an important role in this process, and current hypotheses of organ fibrosis liken it to an aberrant wound healing response in which epithelial-mesenchymal transition (EMT) and cellular senescence may also contribute to disease pathogenesis. The fibrotic response is associated with altered expression of growth factors and cytokines, including increased levels of transforming growth factor- $\beta 1$ (TGF- $\beta 1$ ) and the more recent observation that increased levels of several insulin-like growth factor binding proteins (IGFBPs) are associated with a number of fibrotic conditions. IGFBPs have been implicated in virtually every cell type and process associated with the fibrotic response, making the IGFBPs attractive targets for the development of novel anti-fibrotic therapies. In this review, the current state of knowledge regarding the classical IGFBP family in organ fibrosis will be summarized and the clinical implications considered.
\end{abstract}

Keywords: Extracellular matrix, fibrosis, IGFBP, senescence, systemic sclerosis, idiopathic pulmonary fibrosis.

\section{INTRODUCTION}

Human Insulin-like Growth Factor Binding Proteins (IGFBPs) are a family of circulating proteins which bind Insulin-like Growth Factors-I and II (IGF-I and IGF-II) with high affinity, thereby prolonging the half-life of IGFs as well as modulating their availability and activity. In addition to their IGF-dependent actions, the IGFBPs also exert IGFindependent biological effects that involve neither binding of IGFs nor modulation of the IGF receptor (reviewed in [1-6]).

There are six "classical" IGFBPs, designated IGFBP-1 through IGFBP-6, with highly conserved N-terminal and Cterminal regions flanking non-conserved central domains. Despite structural similarities and binding of IGFs, the human IGFBPs have diverse functional properties including variable binding to the extracellular matrix and differing posttranslational modifications including glycosylation and phosphorylation. These properties contribute to IGFBP bioavailability through mechanisms such as altered IGF binding affinity or protection of IGFBPs from proteolytic digestion by IGFBP-specific proteases (reviewed in $[1,2,4-$ $6]$ ). The IGFBP superfamily also includes several IGFBPrelated proteins (IGFBP-rP) that share homology with the IGFBPs within the N-terminal domains, but lack the highly conserved C-terminal region and bind IGFs with lower affinity (reviewed in $[2,5]$ ).

\footnotetext{
*Address correspondence to this author at the Division of Pulmonary, Allergy, and Critical Care Medicine, Department of Medicine, University of Pittsburgh School of Medicine, NW 628 MUH, 3459 Fifth Ave., Pittsburgh, PA 15213, USA; Tel: 412-692-2210; Fax: 412-692-2260;

E-mail: feghalica@upmc.edu
}

\section{EXPRESSION PATTERNS AND BIOLOGICAL FUNCTIONS OF IGFBPS}

Most cell types produce one or more members of the IGFBP family, and cell-specific IGFBP expression profiles result in distinct patterns of IGFBPs in biological fluids, tissues and organs (reviewed in $[7,8]$ ). The liver is the major source of circulating IGFs and IGFBPs (reviewed in [3]). Hepatocytes synthesize IGFBP-1, -2 and -4 and hepatic Kupffer cells synthesize IGFBP-2 and -3 [9].

IGFBP-3 is the major circulating carrier protein for IGFs and is also a potent anti-proliferative factor at the cellular level, functioning both through cell cycle blockade and induction of apoptosis (reviewed in [10]). IGFBP-5 is the most conserved of the IGFBPs. Only IGFBP-3, -5 and -6 have been demonstrated to possess nuclear localization signals (NLS) and are able to translocate to and localize in the nucleus through an importin-mediated mechanism [1113]. IGFBP-3 NLS interacts most strongly with importin- $\beta$, IGFBP-6 NLS with importin- $\alpha$, and IGFBP-5 NLS binds both importins with roughly equivalent affinity $[11,12]$.

IGFBPs exert cell- and tissue-specific effects and their expression patterns and concentrations are known to vary in a number of pathological states, including fibroproliferative conditions (reviewed in $[14,15]$ ). While the majority of what is known about the IGFBP family has been described in cancer and immortalized cell lines, these effects do not necessarily reflect IGFBP functions in primary nonmalignant cells.

\section{IGF BINDING PROTEINS AS MEDIATORS OF ORGAN FIBROSIS}

In contrast to normal tissue repair and maintenance, organ fibrosis results when excessive fibroblast activation 
leads to deposition of extracellular matrix components and fibroblasts differentiate into contractile myofibroblasts. Despite the fact that fibrosis is a significant cause of morbidity and mortality that can affect any tissue and organ system, there currently are no FDA-approved anti-fibrotic therapies. Identification of druggable targets through a better understanding of the complex biology of fibrosis is of paramount importance.

The fibrotic response is also associated with increased expression of various growth factors and cytokines, including transforming growth factor- $\beta 1$ (TGF- $\beta 1$ ) and connective tissue growth factor (CTGF) (reviewed in [16]). More recently, altered IGFBP expression has also been described in a variety of fibroproliferative conditions. Thus, a better understanding of extracellular matrix regulation by the IGFBPs holds promise for the development of novel antifibrotic therapies. While this goal has yet to be realized, significant progress has been made using animal models of organ fibrosis, ex vivo organ culture, and in vitro cell culture systems.

\section{Skin Fibrosis}

Fibroproliferative disorders of the skin include hypertrophic and keloid scar formation and the classic skin thickening associated with localized and systemic sclerosis (SSc). Keloids are benign but disfiguring dermal tumors that result from aberrant wound-healing and are unique to humans. In contrast to hypertrophic scars, which develop within the boundaries of the original wound and eventually stabilize or regress, keloids grow continuously and invade beyond the original wound margins [17]. Multiple microarray studies have demonstrated upregulation of several of the IGFBP genes in keloid versus normal scar fibroblasts [18-21], including upregulation of IGFBP-3 when cells were cultured in the presence of hydrocortisone [18]. At the protein level, IGFBP-5 is increased in fibroblasts cultured from keloid nodules and in vivo in proliferative keloid tissue [22]. Using a fibroblast-keratinocyte co-culture system, Phan and colleagues demonstrated complex regulation of several IGFBPs in normal versus keloidderived fibroblasts [23]. They noted increased IGFBP-3 mRNA and secreted protein when normal skin fibroblasts were cultured with keloid-derived keratinocytes, but interestingly observed reduced IGFBP-3 levels from keloidderived fibroblasts cultured under identical conditions. Addition of recombinant human IGFBP-3 to the culture media inhibited proliferation of keloid-derived fibroblasts, although the authors do not comment on whether extracellular matrix production was affected. These observations led Phan and colleagues to propose modulation of IGFBP-3 as a potential therapy for keloids.

We have described increased expression of IGFBP-3 and -5 in primary cultures of fibroblasts from the affected skin of patients with SSc $[24,25]$. In support of a mechanistic link between the IGFBPs and the development of fibrosis, we have demonstrated that IGFBP-3 and IGFBP-5 induce a fibrotic phenotype in fibroblasts in vitro [26] and that IGFBP-5 triggers dermal fibrosis in mice in vivo [27]. Using a novel ex vivo human skin organ culture model optimized in our laboratory, we have demonstrated that both IGFBP-3 and IGFBP-5 cause sustained increases in dermal and collagen bundle thickness in human skin explant culture [25]. The pro-fibrotic effects of IGFBP-3 and IGFBP-5 on normal skin do not generalize to all IGFBP family members, as IGFBP-4 does not result in dermal fibrosis and thickening in the same model [25].

\section{Allergic Airway Remodeling and Pulmonary Fibrosis}

Increased levels of IGFBP-3 and -5 have been demonstrated in several fibrotic pulmonary diseases [26, 28]. In a subset of patients with asthma, irreversible airflow obstruction may result from airway remodeling that includes characteristic subepithelial fibrosis and myofibroblast hyperplasia. Cohen and colleagues have demonstrated that the growth-stimulatory effect of TGF- $\beta 1$ on human airway smooth muscle cells in vitro requires IGFBP-3 [29]. We have demonstrated that IGFBP-3 is increased in vivo in the airway epithelium of patients with asthma and that the concentration of IGFBP-3 in bronchoalveolar lavage fluid is increased after allergen challenge [28]. These observations suggest that IGFBP-3 secreted by the epithelium may act locally on airway fibroblasts and contribute to allergic airway remodeling in susceptible individuals.

Pulmonary sarcoidosis is a granulomatous disorder of unknown etiology that in a minority of affected individuals progresses to irreversible fibrotic lung remodeling [30]. Immunoblot analysis of bronchoalveolar lavage fluid from individuals with stage III sarcoidosis versus normal controls demonstrated increased IGFBP-3 [31]. It remains to be determined whether IGFBP expression profiles in stages I, II or III sarcoidosis may predict which individuals will go on to develop stage IV fibrotic disease. It is also unknown whether increased IGFBP-3 contributes directly to the development of sarcoid-associated pulmonary fibrosis, which would make this an attractive target for future therapies.

Idiopathic Pulmonary Fibrosis (IPF) is a progressive fibrotic disease of unknown etiology. Increased IGFBP-3 has been demonstrated in the bronchoalveolar lavage fluid of individuals with IPF [32]. Both IGFBP-3 and IGFBP-5 are increased in IPF lung tissue as well as in primary fibroblasts cultured from these tissues [26]. In support of a mechanistic link between the IGFBPs and pulmonary fibrosis, we have demonstrated that IGFBP-5 causes pulmonary fibrosis in mice [27] and interestingly also induces migration of primary human lung fibroblasts in vitro [33].

In addition to the hallmark skin thickening, systemic sclerosis is also associated with internal organ fibrosis. Based upon observations in SSc skin fibrosis and in IPF, it is reasonable to postulate that altered IGFBP expression also contributes to the development of SSc-associated pulmonary fibrosis. We have recently reported increased expression of several members of the IGF/IGFBP family in lung disease associated with SSc [34]. We have also observed that there is increased expression of the extracellular matrix glycoprotein Tenascin-C (TN-C) in vivo in lung tissue from individuals with SSc-associated pulmonary fibrosis versus normal human lung tissue [35]. Furthermore, IGFBP-3 induces TN$\mathrm{C}$ production in primary human lung fibroblasts. Although TN-C and IGFBP-3 do not co-localize in individual cells, $\mathrm{TN}-\mathrm{C}$ expression is detected in a subepithelial distribution around distal airways of SSc in regions underlying IGFBP-3expressing epithelial cells [35]. This suggests that IGFBP-3 
secreted from distal airway epithelial cells may act locally on resident fibroblasts to increase extracellular matrix deposition and contribute to the development of fibrosis.

\section{Gastrointestinal and Hepatic Fibrosis}

The gastrointestinal tract is involved in a significant majority of patients with systemic sclerosis [36]. Based upon the association between IGFBP-3 and -5 and SSc-associated skin and pulmonary fibrosis, it is reasonable to hypothesize that the IGFBPs may be aberrantly expressed in the GI tract. This remains an unanswered question in the literature.

In Crohn disease, intestinal stricture formation affects approximately $30 \%$ of individuals and is a significant cause of morbidity [37]. IGFBP-5 is highly expressed in inflamed and fibrotic versus normal-appearing intestine in an experimental model of inflammatory bowel disease [38, 39] and in patients with Crohn Disease [40]. More recently it was reported that expression of IGFBP-3 mRNA and protein are significantly increased in smooth muscle cells isolated from intestinal strictures versus non-strictured, histologically normal resection margins from Crohn disease patients [41].

In the injured liver, activated hepatic stellate cells can differentiate into myofibroblasts that are responsible for fibrosis and ultimately cirrhosis. Comparison of the transcriptomes of quiescent, activated and transdifferentiated human hepatic stellate cells in vitro revealed that the expression of only a minority (less than 5\%) of genes changed significantly, including induction of IGFBPs-3, -4, 5 and -6 with IGFBP-5 demonstrating the most dramatic increase [42]. The authors validated this observation in vivo in a mouse model of liver fibrosis, in which RT-qPCR analysis demonstrated a 10-fold up-regulation of collagen I $\alpha 1$ and a 9-fold induction of IGFBP-5. In subsequent in vitro work using LX2 cells (a model for partially activated hepatic stellate cells) and human primary liver myofibroblasts, IGFBP-5 enhanced survival of both cell types via suppression of apoptosis through an IGFindependent mechanism and increased the expression of markers of fibrosis, including collagen I $\alpha 1$ [43].

\section{INTERACTIONS WITH A CLASSICAL MEDIATOR OF FIBROSIS, TGF- $\beta$, AND SIGNALING PATHWAYS}

IGF binding proteins, particularly IGFBP-3 and IGFBP5 , have emerged in the literature with increasing frequency over the past two decades as important markers and mediators of organ fibrosis. Some of their actions are intertwined with classical mediators of fibrosis, such as TGF- $\beta$, whereas others are separate and distinct.

Fibroblasts and myofibroblasts are central cell types in normal wound healing as well as in the aberrant program leading to pathologic fibrosis. Myofibroblasts are mesenchymal cells that display characteristics of both fibroblasts and smooth muscle cells [44]. TGF- $\beta 1$ can induce differentiation of fibroblasts into myofibroblasts through a Smad3-dependent mechanism [45]. We have demonstrated that expression of IGFBP-5 in dermal and pulmonary fibroblasts induces $\alpha$-SMA and vimentin [27], suggesting that IGFBP-5 is also capable of inducing differentiation of fibroblasts into myofibroblasts. IGFBP-5 induces production of extracellular matrix by fibroblasts independently of IGF-I and via activation of MAPK signaling [46]. Additionally, we have demonstrated that early growth response (Egr)-1 is upregulated by IGFBP-5 in a MAPK-dependent manner and is required for IGFBP-5-dependent induction of extracellular matrix production [46]. In further support of the hypothesis that IGFBP-5 promotes fibrosis through an Egr-1-mediated pathway, we have demonstrated increased Egr-1 levels in vivo in lung tissues and in vitro in primary fibroblasts of patients with IPF [46].

Treatment of primary lung fibroblasts with recombinant TGF- $\beta 1$ results in a time-dependent increase in secreted IGFBP-3 protein, but not of secreted IGFBP-5 protein [26]. Direct stimulation of primary lung fibroblasts with recombinant IGFBP-3 induces production of the extracellular matrix components Tenascin-C (TN-C) and collagen I $\alpha 1$, whereas silencing of IGFBP-3 inhibits TGF$\beta 1$-induced production of TN-C but has no effect on TGF- $\beta 1$ induction of collagen $\mathrm{I} \alpha 1$ [35]. These observations suggest that IGFBP-3 and TGF- $\beta$ regulate extracellular matrix composition through both related and independent mechanisms. In fact, we have demonstrated that increased production of TN-C by both TGF- $\beta 1$ and IGFBP-3 requires the p38 mitogen-activated protein kinase (p38MAPK) pathway, although the c-Jun NH2-terminal kinase (JNK) pathway is required only by TGF- $\beta 1$ [35].

The epithelial compartment is also implicated in the pathogenesis of fibrosis, and it is in the epithelium that IGFBP-5 and TGF- $\beta$ have been demonstrated to have distinct effects (reviewed in [47]). It is well-recognized that TGF- $\beta$ is pro-apoptotic and capable of inducing epithelialmesenchymal transition in a subset of epithelial cells (reviewed in [14, 48]). In contrast, IGFBP-5 has been demonstrated to promote increased cell spreading, migration, and laminin production [47, 49]. Cross-talk between injured epithelium and adjacent mesenchymal cells is likely central to the pathogenesis of fibrosis, and IGFBP-5 is upstream of and may activate TGF- $\beta$ [50], therefore IGFBP-5 may represent a more viable therapeutic target than TGF- $\beta$. For thoughtful and comprehensive discussions of TGF- $\beta$ and IGFBP-5 in fibrosis, the reader is directed to two recent reviews by Allan et al. [50] and Sureshbabu et al. [14].

\section{IGFBPS AS THE LINK BETWEEN SENESCENCE AND FIBROSIS}

A revised vision of fibrogenesis has been prompted by the failure of immunosuppressive therapies to modify the progression of fibroproliferative disorders such as IPF and some forms of autoimmune interstitial lung disease (reviewed in [50]). One current hypothesis is that of an unregulated wound healing response [51], in which recurrent cycles of epithelial injury and repair lead to the activation, migration and transdifferentiation of mesenchymal fibroblasts and over-stimulation of this pathway results in excess deposition of extracellular matrix and fibrosis. Another related hypothesis extends this concept by linking fibrosis to senescence, proposing that repeated cycles of epithelial injury exhaust the ability of the affected epithelial cells to proliferate and they enter a state of replicative senescence. Fibroblasts then "fill in" where the epithelial cells have failed as a compensatory injury repair mechanism.

Cell senescence is somewhat broadly defined as an irreversible arrest of growth or proliferation and can be 
triggered by telomere shortening or different forms of stress. Cellular senescence is associated with the aging process, and fibrosis is a well-recognized hallmark of aging in various organs. Additionally, for many fibroproliferative disorders increasing age is correlated with an acceleration of fibrosis. This is the case in IPF, which has been recognized for decades to increase in prevalence with age $[52,53]$ and more recently has been associated with short telomeres and with telomerase mutations in the familial form [54-58]. Interestingly, IPF is also more common in smokers [53, 59] and cigarette smoke extract has been reported to induce senescence in cultured lung fibroblasts and epithelial cells via down-regulation of Werner syndrome protein [60, 61].

Although senescent cells no longer proliferate, they do remain metabolically active and produce secreted growth factors and extracellular matrix components (reviewed in $[62,63])$. IGFBP-3, $-4,-5$ and -6 have been reported to increase in different models of senescence. IGFBP-5 is significantly increased in human dermal fibroblasts and endothelial cells during replicative senescence [64-68]. IGFBP-3 is also increased in senescent human fibroblasts [69] and in the conditioned medium of human fibroblasts derived from older donors and from individuals with Werner syndrome of premature aging [70].

Rather than merely serving as markers of senescence, IGFBPs may play a direct role in the regulation of the senescence program. Using a human umbilical vein endothelial cell (HUVEC) model, Kim and colleagues have demonstrated that knockdown of IGFBP-5 or IGFBP-3 partially reverses senescence phenotypes in old HUVECs and that over-expression of or treatment with exogenous IGFBP-5 or IGFBP-3 induces senescence in young HUVECs $[71,72]$.

The relationship between IGFBPs, fibrosis, and senescence likely applies to subsets of fibrotic disorders and cannot be generalized at this point as IGFBP levels have not been evaluated in a comprehensive manner in all fibrotic disorders and affected organs.

\section{CLINICAL IMPLICATIONS: IGFBPS AS TARGETS FOR ANTI-FIBROTIC THERAPY}

Significant attention has been turned to targeting the major pro-fibrotic cytokine, TGF- $\beta 1$, in an attempt to develop novel anti-fibrotic therapies. Indeed, TGF- $\beta 1$ contributes to many fibrotic processes including fibroblast differentiation into myofibroblasts, increased deposition of extracellular matrix, and epithelial-mesenchymal transition (reviewed in [73]). Unfortunately, this approach has not yet met with significant success, and it is likely that multi-target combinatorial approaches will be required. Furthermore, the biology of the TGF- $\beta$ family is complex and plays an important role in maintenance of homeostasis in multiple cellular compartments, including the immune system. In certain contexts TGF- $\beta$ acts as a tumor suppressor. For example, loss of TGF- $\beta$ signaling in fibroblasts has been implicated in the development of adjacent epithelial neoplasms in an animal model [74]. Thus, there is a need to explore alternative targets for anti-fibrotic therapy.

Altered IGFBP expression has also been described in virtually every cell type and biologic process implicated in the pathogenesis of fibrotic disease. IGFBP-5 has been implicated in epithelial apoptosis, epithelial-mesenchymal transition, fibroblast activation and transdifferentiation to the myofibroblast phenotype, and cellular senescence (reviewed in [50]). IGFBP-5 is upstream of and may activate TGF- $\beta$ [50]. TGF- $\beta 1$ growth inhibition and apoptosis can be mediated through IGFBP-3, and IGFBP-3 mRNA and protein expression is stimulated by TGF- $\beta 1$ in several cell types [75-77]. IGFBP-3 has also been reported to activate TGF- $\beta$ receptors and in some cases to directly inhibit cell growth independently of TGF- $\beta 1$ [78]. The IGFBPs serve these and likely additional functions that are both complementary to and independent of TGF- $\beta$, and therefore represent attractive targets for the development of novel antifibrotic therapies. These therapies could conceivably involve silencing these IGFBPs, interrupting their cellular uptake and/or translocation, blocking their interaction with downstream effectors such as Egr-1, introducing a decoy receptor for the secreted forms of the proteins, or identifying components of potential negative regulatory loops that can be used for blocking the pro-fibrotic effects of IGFBP-3 and -5. Development of small molecule inhibitors of IGFBP action is another potential therapeutic modality that is currently under investigation. These approaches in combination with TGF- $\beta$ targeting therapies, such as the inhibition of TGF- $\beta$ activation and the neutralization of interacting integrins, hold much promise for the treatment of organ fibrosis.

\section{CONCLUSIONS}

Fibrotic diseases have been described in virtually every tissue and organ system and cause significant morbidity and mortality. There currently are no FDA-approved anti-fibrotic therapies, highlighting the need for a better understanding of the molecular mechanisms of fibrosis and the development of novel classes of therapeutic agents. The IGFBPs regulate multiple steps of the fibrotic cascade and thus hold great promise as druggable targets in the continuing quest to cure fibrosis.

\section{ACKNOWLEDGEMENT}

The authors are supported by NIH K08 HL094764 (KLV) and R01 AR050840 (CFB).

\section{CONFLICT OF INTEREST}

The authors have no conflicts of interest to disclose.

\section{REFERENCES}

[1] Bach LA, Headey SJ, Norton RS. IGF-binding proteins--the pieces are falling into place. Trends Endocrinol Metab 2005; 16(5): 22834.

[2] Rosenfeld RG, Hwa V, Wilson E, Plymate SR, Oh Y. The insulinlike growth factor-binding protein superfamily. Growth Horm IGF Res 2000; 10 (Suppl A): S16-7.

[3] Gourmelen M, Perin L, Le Bouc Y. IGFs and their binding proteins. Nucl Med Biol 1994; 21(3): 297-302.

[4] Baxter RC. Insulin-like growth factor (IGF)-binding proteins: interactions with IGFs and intrinsic bioactivities. Am J Physiol Endocrinol Metab 2000; 278(6): E967-76.

[5] Hwa V, Oh Y, Rosenfeld RG. The insulin-like growth factorbinding protein (IGFBP) superfamily. Endocr Rev 1999; 20(6): 761-87.

[6] Clemmons DR. Role of insulin-like growth factor binding proteins in controlling IGF actions. Mol Cell Endocrinol 1998; 140(1-2): 19-24. 
[7] Holly JM, Gunnell DJ, Davey Smith G. Growth hormone, IGF-I and cancer. Less intervention to avoid cancer? More intervention to prevent cancer? J Endocrinol 1999; 162(3): 321-30.

[8] Murphy LJ. Insulin-like growth factor-binding proteins: functional diversity or redundancy? J Mol Endocrinol 1998; 21(2): 97-107.

[9] Scharf J, Ramadori G, Braulke T, Hartmann H. Synthesis of insulinlike growth factor binding proteins and of the acid-labile subunit in primary cultures of rat hepatocytes, of Kupffer cells, and in cocultures: regulation by insulin, insulinlike growth factor, and growth hormone. Hepatology 1996; 23(4): 818-27.

[10] Baxter RC. Signalling pathways involved in antiproliferative effects of IGFBP-3: a review. Mol Pathol 2001; 54(3): 145-8.

[11] Schedlich LJ, Le Page SL, Firth SM, Briggs LJ, Jans DA, Baxter RC. Nuclear import of insulin-like growth factor-binding protein-3 and -5 is mediated by the importin beta subunit. J Biol Chem 2000; 275(31): 23462-70.

[12] Iosef C, Gkourasas T, Jia CY, Li SS, Han VK. A functional nuclear localization signal in insulin-like growth factor binding protein-6 mediates its nuclear import. Endocrinology 2008; 149(3): 1214-26.

[13] Iosef C, Vilk G, Gkourasas T, et al. Insulin-like growth factor binding protein-6 (IGFBP-6) interacts with DNA-end binding protein Ku80 to regulate cell fate. Cell Signal 2010; 22(7): 103343.

[14] Sureshbabu A, Tonner E, Allan GJ, Flint DJ. Relative Roles of TGF- $\beta$ and IGFBP-5 in Idiopathic Pulmonary Fibrosis. Pulm Med 2011; $2011: 517687$.

[15] Ruan W, Ying K. Abnormal expression of IGF-binding proteins, an initiating event in idiopathic pulmonary fibrosis? Pathol Res Pract 2010; 206(8): 537-43.

[16] Leask A, Abraham DJ. TGF-beta signaling and the fibrotic response. FASEB J 2004; 18(7): 816-27.

[17] Murray JC. Keloids and hypertrophic scars. Clin Dermatol 1994; 12(1): 27-37.

[18] Smith JC, Boone BE, Opalenik SR, Williams SM, Russell SB. Gene profiling of keloid fibroblasts shows altered expression in multiple fibrosis-associated pathways. J Invest Dermatol 2008; 128(5): 1298-310.

[19] Satish L, Lyons WJ, Hebda PA, Wells A. Gene expression patterns in isolated keloid fibroblasts. Wound Repair Regen 2006; 14(4): 463-70.

[20] Chen W, Fu X, Sun X, Sun T, Zhao Z, Sheng Z. Analysis of differentially expressed genes in keloids and normal skin with cDNA microarray. J Surg Res 2003; 113(2): 208-16.

[21] Seifert O, Bayat A, Geffers R, et al. Identification of unique gene expression patterns within different lesional sites of keloids. Wound Repair Regen 2008; 16(2): 254-65.

[22] Russell SB, Russell JD, Trupin KM, et al. Epigenetically altered wound healing in keloid fibroblasts. J Invest Dermatol 2010; 130(10): 2489-96

[23] Phan TT, Lim IJ, Bay BH, et al. Role of IGF system of mitogens in the induction of fibroblast proliferation by keloid-derived keratinocytes in vitro. Am J Physiol Cell Physiol 2003; 284(4): C860-9.

[24] Feghali CA, Wright TM. Identification of multiple, differentially expressed messenger RNAs in dermal fibroblasts from patients with systemic sclerosis. Arthritis Rheum 1999; 42(7): 1451-7.

[25] Yasuoka H, Larregina AT, Yamaguchi Y, Feghali BCA. Human skin culture as an ex vivo model for assessing the fibrotic effects of insulin-like growth factor binding proteins. Open Rheumatol J 2008; 2: 17-22.

[26] Pilewski JM, Liu L, Henry AC, Knauer AV, Feghali BCA. Insulinlike growth factor binding proteins 3 and 5 are overexpressed in idiopathic pulmonary fibrosis and contribute to extracellular matrix deposition. Am J Pathol 2005; 166(2): 399-407.

[27] Yasuoka H, Zhou Z, Pilewski JM, Oury TD, Choi AMK, Feghali BCA. Insulin-like growth factor-binding protein-5 induces pulmonary fibrosis and triggers mononuclear cellular infiltration. Am J Pathol 2006; 169(5): 1633-42.

[28] Veraldi KL, Gibson BT, Yasuoka H, et al. Role of insulin-like growth factor binding protein-3 in allergic airway remodeling. Am J Respir Crit Care Med 2009; 180(7): 611-7.

[29] Cohen P, Rajah R, Rosenbloom J, Herrick DJ. IGFBP-3 mediates TGF-beta1-induced cell growth in human airway smooth muscle cells. Am J Physiol Lung Cell Mol Physiol 2000; 278(3): L545-51.

[30] Statement on sarcoidosis. Joint Statement of the American Thoracic Society (ATS), the European Respiratory Society (ERS) and the World Association of Sarcoidosis and Other Granulomatous Disorders (WASOG) adopted by the ATS Board of Directors and by the ERS Executive Committee, February 1999. Am J Respir Crit Care Med 1999; 160(2): 736-55.

[31] Allen JT, Bloor CA, Knight RA, Spiteri MA. Expression of insulinlike growth factor binding proteins in bronchoalveolar lavage fluid of patients with pulmonary sarcoidosis. Am J Respir Cell Mol Biol 1998; 19(2): 250-8.

[32] Aston C, Jagirdar J, Lee TC, Hur T, Hintz RL, Rom WN. Enhanced insulin-like growth factor molecules in idiopathic pulmonary fibrosis. Am J Respir Crit Care Med 1995; 151(5): 1597-603.

[33] Yasuoka H, Yamaguchi Y, Feghali BCA. The pro-fibrotic factor IGFBP-5 induces lung fibroblast and mononuclear cell migration. Am J Respir Cell Mol Biol 2009; 41(2): 179-88.

[34] Hsu E, Shi H, Jordan RM, Lyons WJ, Pilewski JM, Feghali BCA. Lung tissues in patients with systemic sclerosis have gene expression patterns unique to pulmonary fibrosis and pulmonary hypertension. Arthritis Rheum 2011; 63(3): 783-94.

[35] Brissett M, Veraldi K, Pilewski J, Medsger T, Feghali-Bostwick C. Localized expression of tenascin in systemic sclerosis-associated lung fibrosis and its regulation by IGF binding protein (IGFBP)-3. Arthritis Rheum 2012; 64: 272-80.

[36] Rose S, Young MA, Reynolds JC. Gastrointestinal manifestations of scleroderma. Gastroenterol Clin North Am 1998; 27(3): 563-94.

[37] Loftus EV. Clinical epidemiology of inflammatory bowel disease: Incidence, prevalence, and environmental influences. Gastroenterology 2004; 126(6): 1504-17.

[38] Zeeh JM, Hoffmann P, Sottili M, Eysselein VE, McRoberts JA. Up-regulation of insulinlike growth factor I binding sites in experimental colitis in rats. Gastroenterology 1995; 108(3): 644-52.

[39] Zimmermann EM, Li L, Hou YT, Cannon M, Christman GM, Bitar KN. IGF-I induces collagen and IGFBP-5 mRNA in rat intestinal smooth muscle. Am J Physiol 1997; 273(4 Pt 1): G875-82.

[40] Zimmermann EM, Li L, Hoyt EC, Pucilowska JB, Lichtman S, Lund PK. Cell-specific localization of insulin-like growth factor binding protein mRNAs in rat liver. Am J Physiol Gastrointest Liver Physiol 2000; 278(3): G447-57.

[41] Flynn RS, Mahavadi S, Murthy KS, et al. Endogenous IGFBP-3 regulates excess collagen expression in intestinal smooth muscle cells of Crohn's disease strictures. Inflamm Bowel Dis 2011; 17(1): 193-201.

[42] Boers W, Aarrass S, Linthorst C, Pinzani M, Elferink RO, Bosma P. Transcriptional profiling reveals novel markers of liver fibrogenesis: gremlin and insulin-like growth factor-binding proteins. J Biol Chem 2006; 281(24): 16289-95.

[43] Sokolović A, Sokolović M, Boers W, Elferink RP, Bosma PJ. Insulin-like growth factor binding protein 5 enhances survival of LX2 human hepatic stellate cells. Fibrogenesis Tissue Repair 2010; 3: 3 .

[44] Sappino AP, Schürch W, Gabbiani G. Differentiation repertoire of fibroblastic cells: expression of cytoskeletal proteins as marker of phenotypic modulations. Lab Invest 1990; 63(2): 144-61.

[45] $\mathrm{Hu}$ B, Wu Z, Phan SH. Smad3 mediates transforming growth factor-beta-induced alpha-smooth muscle actin expression. Am J Respir Cell Mol Biol 2003; 29(3 Pt 1): 397-404.

[46] Yasuoka H, Hsu E, Ruiz XD, Steinman RA, Choi AM, Feghali BCA. The fibrotic phenotype induced by IGFBP-5 is regulated by MAPK activation and egr-1-dependent and -independent mechanisms. Am J Pathol 2009; 175(2): 605-15.

[47] Sureshbabu A, Okajima H, Yamanaka D, et al. IGFBP-5 induces epithelial and fibroblast responses consistent with the fibrotic response. Biochem Soc Trans 2009; 37(Pt 4): 882-5.

[48] Massagué J, Blain SW, Lo RS. TGFbeta signaling in growth control, cancer, and heritable disorders. Cell 2000; 103(2): 295309 .

[49] Abrass CK, Hansen KM. Insulin-like growth factor-binding protein-5-induced laminin gammal transcription requires filamin A. J Biol Chem 2010; 285(17): 12925-34.

[50] Allan GJ, Beattie J, Flint DJ. Epithelial injury induces an innate repair mechanism linked to cellular senescence and fibrosis involving IGF-binding protein-5. J Endocrinol 2008; 199(2): 15564.

[51] Selman M, Pardo A. Role of epithelial cells in idiopathic pulmonary fibrosis: from innocent targets to serial killers. Proc Am Thorac Soc 2006; 3(4): 364-72. 
[52] American Thoracic Society. Idiopathic pulmonary fibrosis: diagnosis and treatment. International consensus statement. American Thoracic Society (ATS), and the European Respiratory Society (ERS). Am J Respir Crit Care Med 2000; 161(2 Pt 1): 64664.

[53] Raghu G, Weycker D, Edelsberg J, Bradford WZ, Oster G. Incidence and prevalence of idiopathic pulmonary fibrosis. Am J Respir Crit Care Med 2006; 174(7): 810-6.

[54] Alder JK, Chen JJ, Lancaster L, et al. Short telomeres are a risk factor for idiopathic pulmonary fibrosis. Proc Natl Acad Sci USA 2008; 105(35): 13051-6.

[55] Cronkhite JT, Xing C, Raghu G, et al. Telomere shortening in familial and sporadic pulmonary fibrosis. Am J Respir Crit Care Med 2008; 178(7): 729-37.

[56] Armanios MY, Chen JJ, Cogan JD, et al. Telomerase mutations in families with idiopathic pulmonary fibrosis. N Engl J Med 2007; 356(13): 1317-26.

[57] Garcia CK, Wright WE, Shay JW. Human diseases of telomerase dysfunction: insights into tissue aging. Nucleic Acids Res 2007; 35(22): 7406-16.

[58] Garcia CK. Idiopathic pulmonary fibrosis: update on genetic discoveries. Proc Am Thorac Soc 2011; 8(2): 158-62.

[59] Baumgartner KB, Samet JM, Stidley CA, Colby TV, Waldron JA. Cigarette smoking: a risk factor for idiopathic pulmonary fibrosis. Am J Respir Crit Care Med 1997; 155(1): 242-8.

[60] Nyunoya T, Monick MM, Klingelhutz A, Yarovinsky TO, Cagley JR, Hunninghake GW. Cigarette smoke induces cellular senescence. Am J Respir Cell Mol Biol 2006; 35(6): 681-8.

[61] Nyunoya T, Monick MM, Klingelhutz AL, et al. Cigarette smoke induces cellular senescence via Werner's syndrome protein downregulation. Am J Respir Crit Care Med 2009; 179(4): 279-87.

[62] Roninson IB. Tumor cell senescence in cancer treatment. Cancer Res 2003; 63(11): 2705-15.

[63] Kuilman T, Peeper DS. Senescence-messaging secretome: SMSing cellular stress. Nat Rev Cancer 2009; 9(2): 81-94.

[64] Suzuki T, Minagawa S, Michishita E, et al. Induction of senescence-associated genes by 5-bromodeoxyuridine in HeLa cells. Exp Gerontol 2001; 36(3): 465-74.

[65] Dokmanovic M, Chang BD, Fang J, Roninson IB. Retinoidinduced growth arrest of breast carcinoma cells involves coactivation of multiple growth-inhibitory genes. Cancer Biol Ther 2002; 1(1): 24-7.

[66] Chang BD, Swift ME, Shen M, Fang J, Broude EV, Roninson IB. Molecular determinants of terminal growth arrest induced in tumor cells by a chemotherapeutic agent. Proc Natl Acad Sci USA 2002; 99(1): 389-94.

[67] Yoon IK, Kim HK, Kim YK, et al. Exploration of replicative senescence-associated genes in human dermal fibroblasts by cDNA microarray technology. Exp Gerontol 2004; 39(9): 1369-78.

[68] Hampel B, Fortschegger K, Ressler S, et al. Increased expression of extracellular proteins as a hallmark of human endothelial cell in vitro senescence. Exp Gerontol 2006; 41(5): 474-81.

[69] Moerman EJ, Thweatt R, Moerman AM, Jones RA, Goldstein S. Insulin-like growth factor binding protein-3 is overexpressed in senescent and quiescent human fibroblasts. Exp Gerontol 1993 28(4-5): 361-70

[70] Goldstein S, Moerman EJ, Baxter RC. Accumulation of insulin-like growth factor binding protein-3 in conditioned medium of human fibroblasts increases with chronologic age of donor and senescence in vitro. J Cell Physiol 1993; 156(2): 294-302.

[71] Kim KS, Seu YB, Baek SH, et al. Induction of cellular senescence by insulin-like growth factor binding protein-5 through a p53dependent mechanism. Mol Biol Cell 2007; 18(11): 4543-52.

[72] Kim KS, Kim MS, Seu YB, Chung HY, Kim JH, Kim JR Regulation of replicative senescence by insulin-like growth factorbinding protein 3 in human umbilical vein endothelial cells. Aging Cell 2007; 6(4): 535-45.

[73] Varga J, Pasche B. Antitransforming growth factor-beta therapy in fibrosis: recent progress and implications for systemic sclerosis Curr Opin Rheumatol 2008; 20(6): 720-8.

[74] Bhowmick NA, Chytil A, Plieth D, et al. TGF-beta signaling in fibroblasts modulates the oncogenic potential of adjacent epithelia. Science 2004; 303(5659): 848-51.

[75] Gucev ZS, Oh Y, Kelley KM, Rosenfeld RG. Insulin-like growth factor binding protein 3 mediates retinoic acid- and transforming growth factor beta2-induced growth inhibition in human breast cancer cells. Cancer Res 1996; 56(7): 1545-50.

[76] Martin JL, Ballesteros M, Baxter RC. Insulin-like growth factor-I (IGF-I) and transforming growth factor-beta 1 release IGF-binding protein-3 from human fibroblasts by different mechanisms Endocrinology 1992; 131(4): 1703-10.

[77] Oh Y, Müller HL, Ng L, Rosenfeld RG. Transforming growth factor-beta-induced cell growth inhibition in human breast cancer cells is mediated through insulin-like growth factor-binding protein-3 action. J Biol Chem 1995; 270(23): 13589-92.

[78] Kuemmerle JF, Murthy KS, Bowers JG. IGFBP-3 activates TGFbeta receptors and directly inhibits growth in human intestinal smooth muscle cells. Am J Physiol Gastrointest Liver Physiol 2004; 287(4): G795-802.

This is an open access article licensed under the terms of the Creative Commons Attribution Non-Commercial License (http://creativecommons.org/licenses/by-nc/ $3.0 /$ ) which permits unrestricted, non-commercial use, distribution and reproduction in any medium, provided the work is properly cited. 